\title{
Su Kalitesi Gözlem Ağlarının Performansının Değerlendirilmesi için Bir Yöntem Önerisi ve Gediz Havzasında Uygulanması
}

\section{A Method Proposal for Evaluation of the Performance of Water Quality Monitoring Networks and Application in Gediz River Basin}

\author{
Cem Polat Çetinkaya ${ }^{*} \mathbb{D}$, Sezer Dilek Yiğit ${ }^{1(D)}$ \\ ${ }^{1}$ Dokuz Eylül Üniversitesi Mühendislik Fakültesi İnşaat Mühendisliği Bölümü, İzmir, TÜRKIYE \\ Sorumlu Yazar / Corresponding Author*: cem.cetinkaya@deu.edu.tr \\ Geliş Tarihi / Received: 13.11.2018_ DOI:10.21205/deufmd.2019216214 \\ Kabul Tarihi / Accepted: 24.01.2019 Araștırma Makalesi/Research Article \\ Atıfsekli/How to cite: ÇETINKAYA, C.P., YïĞiT, S.D. (2019). Su Kalitesi Gözlem Ağlarının Performansının Değerlendirilmesi için Bir Yöntem \\ Önerisi ve Gediz Havzasinda Uygulanması. DEUFMD, 21(62), 483-497.
}

\section{Öz}

Su kalitesi gözlem ağlarının tasarımı ve mevcut ağların iyileștirilmesi problemi; gözlem sürekliliği, ölçüm sıklığı ve gözlem konumlarının seçimi ile ilgili belirsizlikler, diğer yandan ise gözlem amaçlarının zaman içerisinde değișmesi gibi nedenlerden dolayı halen çözümü araștırılan bir problemdir. Bu nedenle gözlem ağı tasarımı ve mevcut gözlem ağlarının iyileştirilmesi konusu çok kriterli değerlendirmeye ihtiyaç duymaktadır ve zaman içinde değişen gözlem amaçlarına göre de var olan sistemin uyumlandırılması gerekliliği vardır. Problemin varolan karmașık yapısı nedeniyle halihazırda kesin bir yöntem bulunmamaktadır. Çok kriterli optimizasyon ve karar verme yöntemleri ile yapılan önceki çalışmalarda özellikle kriterlere atanan önem ve ağırlık katsayılarının seçimi gözlem ağı ile ilgili verilen kararları doğrudan etkilemektedir. Sunulan çalışma, ağırlık katsayılarının tayinini gerektirmeyen bir çok kriterli karar verme yöntemi olan Referans Noktası Yöntemini (RNY) esas alarak, su kalitesi gözlem ağı performansını irdelemeyi amaçlamaktadır. Yöntem Gediz havzasına uygulanarak, 1985-2000 yılları arasında gözlemlenen veriler ile mevcut su kalitesi gözlem ağı amaçlarına göre istasyon bazında performans belirlenmiş ve çıkan sonuçlar irdelenmiştir. Referans Noktası Yöntemi gözlem ağı performansı değerlendirmesinde kolaylıkla kullanılabilecek bir yöntem olarak değerlendirilmiştir.

Anahtar Kelimeler: Yüzeysel Su Kalitesi Gözlem Ağı, Gözlem Ağı Performansı, Referans Noktası Yöntemi, Gediz Havzası

\begin{abstract}
Water quality monitoring network design, evaluation and improvement problem is still investigated due to challenges and uncertainties such monitoring continuity, frequency, location and temporal changes in monitoring objectives. Regarding these issues, design and improvement of monitoring networks require multi-criteria evaluation and adaptation of the system to the temporal changes in monitoring objectives. Due to the complex nature of this problem, there is no exact solution yet. Many previous studies employed multi-criteria optimization and decision-making methodologies, however, it is revealed that the elicitation of importance and weighting coefficients assigned to criteria affect the decisions given for the monitoring networks. The presented study aims to evaluate the performance of these networks through the utilization of a multi-criteria decision-making method
\end{abstract}


called "Reference Point Approach", which does not necessitate the assignment of these weights. The method is applied to Gediz Basin and station based network performance is assessed through the use of observations between the years of 1985 and 2000 regarding the existing monitoring objectives,. The obtained results indicate that reference point approach is useful in providing reliable results.

Keywords: Surface Water Quality Monitoring Network, Monitoring Network Performance, Reference Point Approach, Gediz Basin

\section{Giriș}

Su kalitesi; suyun fiziksel, kimyasal ve biyolojik özniteliklerinden olușur. $\mathrm{Bu}$ özniteliklerin tanımlanıp sinıflandırılması, mevcut kalitenin korunması ve gerekliyse iyileştirilmesi için belirli kriterler olușturulması gözlem yapma adımı ile gerçekleşir [1]. Gözlem, belirli amaçlar için veri toplanmasına dayanır ve mevcut durum hakkında bilgi sağlar. Gözlem yapma ihtiyacı; eğilimi belirlemek, modelleme yapmak, uzun dönem tahminlerinde bulunmak gibi amaçlardan doğar. Gözlem yapma ihtiyacında neyin gözlemlendiğini anlamak için "bilgi döngüsü"nü anlamak gerekir. Bilgi döngüsünün oluşturulması için ihtiyaçlar belirlenmeli ve hangi kaynağın hangi bölümden toplanacağını belirleyen bilgi stratejisi hazırlanmalıdır. Bir sonraki adım olan veri toplama, verilerin türüne göre gözlem veya modelleme yoluyla gerçekleștirilebilir. Toplanan veriler analiz edilir ve sonuçlar bilgi ihtiyaçlarına göre yorumlanır [2].

Gözlemlenecek değerlerin belirlenmesi tek başına yeterli değildir. Su kalitesi gözlemi için en önemli adım gözlem ağı tasarımıdır. Gözlemlerin yapılmasında ölçüm yerlerinin seçimi, sıklığın belirlenmesi ve kalite değişkenlerinin tanımlanması gereklidir. Verilerin toplanacağı istasyonların seçimi, belirli kısıtlar altında gerçekleșmelidir. $\mathrm{Bu}$ așamada; istasyonun kurulması gereken akarsu bölümü (makrolokasyon), yapılan deșarj ve akarsu öznitelikleri göz önünde bulundurularak bölgeye kurulacak istasyonun kesin yeri (mikrolokasyon) ve numune alınacak akarsu bölümünde su özniteliklerini en iyi temsil eden noktanın belirlenmesi (temsili lokasyon) așamaları dikkate alınmalıdır. Ayrıca havza topografyası, akım özellikleri, kirlilik deşarjları gibi öznitelikler de yer seçiminde önemli role sahiptir [1]. Gözlem ağı tasarımında kullanılan yöntemler; verinin kullanılabilirliğinin ve içerdiği bilginin tanımlı olmaması, ölçüm konumu ve sıklığına bağlı bilgi transfer yöntemlerinin kısıtllı $\breve{g}_{1}$ gibi sebeplerle yetersiz kalmaktadır [3].

Su kalitesi gözlem ağı tasarımı ve ve tasarlanan ağların hem alansal hem de bilgi içeriği açısından optimizasyonu birçok araştırmacl tarafından incelenmiștir ve halen inceleme konusudur. Sharp, bir ağın çıkışındaki kirletici kaynağının saptanmasındaki belirsizliği ölçmek için Horton 'un yaklaşımını kullanarak dış kolların sayısının temsili su kalitesi değișkeninin kirlilik yüküne dayalı olarak atanmasını önermiştir [4-5]. Tirsch ve Male, çok değişkenli doğrusal regresyon modelini önermişlerdir [6]. Özkul, bilgi teorisinin entropi prensibini su kalitesi gözlem ağlarının alansal ve zamansal olarak belirlenmesinde kullanılabilecek metotlar olarak önermiş ve uygulamıştır [7]. Benzer şekilde, AlZahrani ve Moied, kentsel su dağıtım sistemlerinde optimum su kalitesi örnekleme noktalarının belirlenmesinde Genetik Algoritma (GA) temelli bir metodoloji geliștirmișlerdir [8]. Çetinkaya ve Harmancıoğlu, Gediz Havzası'nda Dinamik Programlama Yöntemi (DPY) ile su kalitesi gözlem ağında korunması gereken minimum istasyon sayısını ve dinamik programlama yönteminde alt havza sayısı seçiminin yöntemin sonuçlarına etkisini incelemiș ve alt havza sayısının tespiti için bir metodoloji geliștirmișlerdir [9]. Villas-Boas v.d. Piabamha Nehri (Brezilya) var olan su kalitesi gözlem istasyonlarının makrolokasyonunu "kendi eşleşen sinir ağı" yöntemi ile irdeleyerek, en az üç adet istasyonun yerlerinin doğru tayin edilmediğini bulmuşlardır [10]. Benzer șekilde Asadollahfardi v.d. Sefid-Rud Nehri su kalitesi gözlem ağını genetik algoritma ile irdelemişlerdir [11]. Mokin v.d. "kompleks dinamik çok değișkenli ve alansal dağılımlı sistem (DMVSDS)" tanımından yola çıkarak Güney Bug (Ukrayna) Nehri su kalitesi gözlem ağının performansını su bütçesi ve yönetim bölgelerini temel alan bir yöntem ile değerlendirmiș ve tanımlanan amaçlara göre bir istasyon sıralaması elde etmișlerdir [12]. Önceki yapılan birçok çalışmada su kalitesi gözlem ağı tasarımında suyun özellikleri, kullanım amaçları 
ve verilerin bilgi içeriğine yönelik hedefler göz önüne alınarak çözümler geliștirilmiștir [13]. Su kalitesi gözlem ağı tasarımında ön görülen amaçlar; su kalitesindeki değişimlerin tespiti, su kirliliği kontrol programlarının geliştirilmesi, belli bir amaç için kullanılan suyun kalite kontrolü, su kalitesi yönetiminin değerlendirilmesi v.b. olarak özetlenebilir. Yapılan önceki çalıșmalar değerlendirildiğinde, su kalitesi gözlem ağlarının tasarımı ve mevcut ağların iyileștirilmesi problemine farklı yaklașımlar uygulanırken problemin genel çözümüne halen ulaşılamamıștır. Bugüne kadar ortaya konulan yöntemlerin çoğu gözlem ağından elde edilen verilerin, istatistiksel bilgi üretimine katkısına odaklandığı için, var olan ağın hangi amaçla kurulduğu ve bu ağın elemanları olan istasyonların (ya da örnekleme noktalarının) bu amaca ya da amaçlara hizmet edip etmedikleri sorusuyla ilgilenmemektedirler. Elde edilen verilerin istasyon ağının işletme amaçlarına ne kadar hizmet ettiği veya var olan istasyonların işletmedeki kolaylık ya da zorluklarını bir arada değerlendirme gerekliliği zaman içinde ortaya çıkmaktadır. İşletilmesinde sorunlar olan gözlem ağlarının genel amaca ne kadar hizmet ettiğini değerlendiren yöntemler de tam anlamıyla geliştirilememiştir. Diğer yandan zaman içinde değișen amaç ve hedeflere yönelik gözlem ağlarının değerlendirilmesi gerekliliği de mevcut ağların öngörülen amaçlara yönelik performanslarının ölçülmesini gerektirmektedir.

Önceki birçok çalıșma, amaçların önem sıralarını belirlemek için ağırlı katsayılarına dayanmaktadır ve bu ağırlık katsayılarının tayini genel olarak nesnel değil öznel çıkarımlara dayanmaktadır. $\mathrm{Bu}$ sorunu așmaya yönelik olarak, "Referans Noktası Yöntemi" ağırlık katsayısı tayin etme zorunluluğu olmadan sıralama yapabilmektedir.

Yapılan çalışmada Gediz Nehri Havzası'nda 1985-2000 yılları arasında ișletilen 33 adet su kalitesi gözlem istasyonu ele alınmıştır. 19852000 yılları arasındaki sıcaklık (T), $\mathrm{Na}, \mathrm{Ca}, \mathrm{Cl}$, elektriksel iletkenlik (EC), bulanıklık (Turb), $\mathrm{NO}_{2}-\mathrm{N}, \mathrm{NO}_{3}-\mathrm{N}, \mathrm{NH}_{3}-\mathrm{N}, \mathrm{SS}$ (askıda katı madde), BOD5, DO (çözünmüș oksijen), COD (Kimyasal oksiyen ihtiyacı) olmak üzere 13 adet kalite değişkeni değerlendirilmiştir. Devlet Su İșleri Genel Müdürlüğü (DSI) verilerinden elde edilen kalite değișkenleri, temsil ettikleri kirlilik çeşitlerine göre sınıflandırılmış ve iki grup altında değerlendirilmiștir. Daha sonra her bir istasyonun drenaj alanı, sulama alanı, nüfus v.b. öznitelikleri değerlendirilerek, bu özniteliklerin katkı koyduğu amaçlar tayin edilmiştir. Su kalitesinin modellenmesi, mevcut durumun tespiti ve uzun süreli değișimlerin tespiti olmak üzere 3 amaca (kriter) göre gözlem ağı performansı referans noktası yöntemi ile değerlendirilmiştir.

\section{Materyal ve Metot}

\subsection{Referans noktası yöntemi ve gözlem ağı performansının değerlendirilmesi problemine uygulanması}

Referans noktası yöntemi, enerji, arazi kullanımı, çevresel modeller, ticaret uygulamaları ve mühendislik tasarımına yönelik çok kriterli karar verme problemlerinde kullanılan bir yöntemdir [14-15-16]. Özellikle, bölgesel su kalitesi yönetimi, arazi kullanımı planlanması, kentsel imar planları, çevresel su tahsisi v.b uygulamalarda bu yöntem başarı ile uygulanmıştır [17]. Referans noktası yaklaşımı, her bir kriter için belirlenen ya da fiziksel olarak var olan en iyi (minimum ya da maksimum) referans değerlerinin tanımlanmasını ve çok kriterli karmașık problemlerin analizinde var olan seçeneklerin bu referans düzeylerine uzaklık ya da yakınlıklarının ölçülerek sıralanmalarına dayanır [18]. Bu yaklaşımın temel amacl, her kritere tayin edilebilecek sübjektif ağırlık katsayılarını kullanmadan daha objektif ve amaç odaklı sonuçların elde edilmesidir [19]. Yöntem, birden fazla referans noktası ile tanımlanan karmașık bileșenli amaçları olan karar verme problemlerinin çözümünde de kullanılmaktadır [20].

Sunulan çalışmada referans noktası yöntemi, su kalitesi gözlem ağlarının performansının değerlendirilmesinde, gözlenen su kalitesi değișkenlerinin çokluğu, her değișkenin farklı kirlilik kaynaklarını tarif etmesi, verilerin düzensizliği ve devamlı olmayıșı, her istasyonun işletme sürelerinin ve işletme amaçlarının farklılığı gibi nedenlerle tercih edilmiştir. Burada vurgulanması gereken en önemli nokta, yukarıda anılan etkenlerin istasyon performansına olan katkılarının tayininde yöntemin ağırlık katsayılarının atanmasına ihtiyaç duymamasıdır. Yöntemin su kalitesi gözlem ağı performasının ölçülmesine uyarlanmasında öncelik, birden fazla amaca hizmet eden ağın istasyon bazında performans değerlendirmesini yaparak en iyi ve en kötü istasyonları tespit etmektir. 
Gözlem amaçlarının gerçekçi ve spesifik olarak tanımlanmaması, ölçüm ağından beklenen bilgi ile üretilen bilgi arasında uyumsuzluklara neden olmakta ve ihtiyaç duyulan bilginin sağlanamamasına yol açmaktadır. Mevcut bir gözlem ağının irdelenmesinde, ağ hakkındaki bilgiler, sorunlar, beklenen bilgi ile yeterliliği, ağın konum ve ölçüm slklığı ve istasyonun spesifik amaçlarının belirlenmesi gereklidir. $\mathrm{Bu}$ belirleme çalışması, amaçların sağlanıp sağlanmadığının değerlendirilmesinde büyük bir öneme sahiptir. Bu özelliklerin periyodik olarak değerlendirilmesi ölçüm ağının sağlıklı ve güvenilir biçimde gelişimini de sağlamaktadır. İstasyonların sıklık, ulaşılabilirlik, veri sayısı, online istasyon olması gibi ortak öznitelikleri ve gözlemlenen verilerin kirlilik temsili açısından sınıflandırılması ölçüm ağı için belirlenmiş gözlem amaçları doğrultusunda yapılmalıdır. İstasyonlarda gözlemlenen çok sayıdaki su kalitesi parametresi arasından seçim yapabilmek ve performansı ölçebilmek için kirlilik envanterlerinin oluşturulması, kalite standartlarına göre kirlilik sınıflarının tayini, potansiyel kirlilik kaynaklarının belirlenmesi gibi ön araștırmalar da gerçekleștirilmelidir [21].

\subsection{1. İstasyonları temsil eden özniteliklerin seçimi}

Bir gözlem ağındaki her istasyon, havza yönetim hedeflerine ve operasyonel kriterlere uygun öznitelikleriyle tanımlanmalıdır. Bu öznitelikler, gözlem istasyonunu etkileyen fiziki koşulları da göz önünde bulundurarak drenaj alanı, nüfus yoğunluğu, sulama alanı, istasyonun işletme süresi, istasyonun teknolojisi, istasyonun ulașllabilirliği, istasyonun bulunduğu bölgede anlık akım gözlem istasyonlarının varlığı vb. olarak seçilebilir. İstasyona özgü öznitelikleri tanımlamak için gözlem sayısı, verilerin istatistiksel parametreleri, gözlem süresinin uzunluğu ve benzeri öznitelikler de göz önüne alınabilir. İstasyonların öznitelikleri istasyonun istenilen performansını amaca göre ölçen göstergeler olarak değerlendirileceği için, özniteliklerin seçimi ağ performansının istasyon bazında değerlendirilmesi sürecinde önemlidir. Seçilen öznitelikler, ağdaki genel durumu yansitmalı ve toplanan verilere dayanarak elde edilen bilgiler de dahil olmak üzere istasyonun temel özniteliklerini de belirtmelidir. Öte yandan seçilen öznitelikler, ağl olușturan tüm istasyonlar için geçerli olmalıdır ve her bir özelliğin her istasyon için hesaplanması kolay olmalıdır. $\mathrm{Bu}$ durum, istasyonlar arasında bir sıralama olușturarak karșılaștırma yapılmasını mümkün kllar [22].

Belirlenen gözlem ağı işletme amaçlarına, diğer bir deyişle kriterlere hizmet eden öznitelikler farklı birimlerde olacağından istasyonlar için hesaplanan her bir öznitelik değeri tüm değerler göz önüne alınarak önce normalize daha sonra da üniformize edilmelidir. Hesaplanan öznitelik değerlerinin $(0,1)$ aralığında boyutsuz değerler almalarını sağlamak için her istasyona ait öznitelik değerleri Box-Cox dönüşümü Denklem (1) ile normalize edilir.

$$
y_{i}=\frac{x_{i}^{\lambda}-1}{\lambda} \quad \lambda \neq 0 \text { için }
$$

Box-Cox dönüşümünde $\mathrm{y}_{\mathrm{i}}$ dönüştürülen veri, $\mathrm{x}_{\mathrm{i}}$ orijinal çarpık veriler ve $\lambda$, deneme yanılma yöntemi ile tahmin edilecek olan bir parametre değeridir. $\lambda$ değeri çarpıklık katsayısını sıfır ya da sıfıra yakın yapacak bir değer olmalıdır [23]. Normalize edilmiş değerler, Olasılık-İntegral Dönüșümü kullanılarak $(0,1)$ aralığı için üniform bir dağılım fonksiyonuna sahip olmak üzere bir kez daha dönüştürülür. Olasılık İntegral Dönüșümünde, herhangi bir $\mathrm{X}$ rasgele değişkeninin tanımlı ve sürekli $F_{x}$ toplam olasılık dağılımı kullanılarak $\mathrm{Y}=\mathrm{F}_{\mathrm{x}}(\mathrm{X})$ dönüşümüyle üretilen rasgele değișken $\mathrm{Y}$, bașlangıç aralığ $(0,1)$ boyunca uniform olasılık dağılımına sahiptir. Kümülatif fonksiyon F (x), Denklem (2) kullanılarak F(z) olarak standartlaştırılabilir.

$$
z=\frac{x-\mu}{\sigma}
$$

Burada, z standartlaştırılmış normal veri, $\mathrm{x}$ : öznitelik verileri; $\mu$ : aritmetik ortalama; ve $\sigma$ : standart sapmadır. Bu dönüşümden sonra, standartlaştırılmış kümülatif normal dağılım fonksiyonu $F(\mathrm{z})$, Olasıllk-İntegral Dönüşüm teoremine göre kümülatif uniform dağılım fonksiyonuna F (y)'ye eşit olur:

$$
F(z)=F(y)=\frac{y-a}{b-a}
$$

ve böylece

$$
y=(b-a) F(z)+a
$$

elde edilir. Uniform dağılımın sınırları olarak $b=$ 1 ve a $=0$ değerleri alınırsa aşağıdaki eșitlik elde edilir:

$$
y=F(z)
$$


Burada y, normal dağılım fonksiyonlu öznitelik değeri olan $x$ 'in üniformize edilmiș verileri ve $\mathrm{F}(\mathrm{z}), \mathrm{x}^{\prime}$ in standartlaștırılmıș kümülatif normal dağılım fonksiyonudur[23].

Buradan hareketle tanımlanan $Y$ ve $F(y)$ fonksiyonları, özniteliklerin ve referans noktasının çok boyutlu birimsiz bir karar alanında birer nokta veya vektör ile tanımlanmasını mümkün kılar. Bu karar alanını tanımlayan boyutlar ise gözlem ağının amaçlarını temsil eden kriterlerden oluşmaktadır. $\mathrm{Bu}$ sebeple herhangi bir istasyonun özniteliklerinin toplamı ile tarif edilen kriter skoru ve bu kriterlerin karar uzayında temsil ettikleri nokta o istasyonun değerini belirler ve referans noktasına olan mesafesi aracılığı ile de istasyonun performansı belirlenir. Referans noktası, tüm kriterlerin en iyi değerlerinden oluşan bir noktadır.

Normalize ve üniformize ișlemlerinden sonra her bir aij niteliği değeri $(0,1)$ aralığında birimsiz $\mathrm{au}_{\mathrm{ij}}$ değerlerine dönüşecektir. Bu sayede i inci gözlem istasyonu için $\mathrm{n}$ sayıdaki öznitelik ile ilişkili olan $\mathrm{m}$ inci kriterin skoru ( $\mathrm{SC}_{\mathrm{im}}$ ), üniformize edilmiş j inci öznitelik değerlerinin $\left(\mathrm{au}_{\mathrm{ij}}\right)$ toplamı üzerinden așağıdaki gibi elde edilebilir:

$$
S C_{i m}=\sum_{j=1}^{n} a u_{i j}
$$

Her bir özniteliğin maksimum alabileceği değerin "1" olacağı göz önüne alındığında her bir kriterin tarif ettiği referans değeri, özniteliklerin $\left(\mathrm{au}_{\mathrm{ij}}\right)$ toplamından ibaret hale gelecektir. Diğer yandan $\mathrm{n}$ adet kriterin tanımlandığı bir karar uzayının boyutları da kriter sayısı kadar olacaktır. Burada her bir istasyon için hesaplanan kriter skorları $\mathrm{n}$ boyutlu uzayda bir noktayı tarif ederler. Buna göre tanımlanmıș referans noktasına en yakın olan istasyon, kriterlerin tümünü en iyi başaran istasyon olacaktır. $\mathrm{Bu}$ yakınlığın ölçümünde Öklid mesafesi kullanılır; örneğin iki boyutlu bir Öklid uzayında A ve B gibi iki nokta arasındaki mesafe $A\left(\mathrm{x}_{\mathrm{A}}, \mathrm{y}_{\mathrm{A}}\right)$ ve $\mathrm{B}\left(\mathrm{x}_{\mathrm{B}}, \mathrm{y}_{\mathrm{B}}\right)$ koordinatları biliniyorsa;

$$
D_{A-B}=\left(\left(x_{B}-x_{A}\right)^{2}+\left(y_{B}-y_{A}\right)^{2}\right)^{\frac{1}{2}}
$$

şeklinde hesaplanır.

Bir başka örnek vermek gerekirse, üç boyutlu bir karar uzayında herhangi bir "i" istasyonu $\left\{\mathrm{SC}_{\mathrm{i} 1}\right.$, $\mathrm{SC}_{\mathrm{i} 2}, \mathrm{SC}_{\mathrm{i} 3}$ koordinatlarıly tek bir noktada temsil edilir. Şekil 1'de görüldüğü gibi, benzer biçimde referans noktası da her kriter ile ilişkili özniteliklerin toplam sayısına karşılık gelen üç boyutlu koordinatlara $\{n 1, n 2, n 3\}$ sahiptir. Örneğin 3 adet öznitelik ile tanımlanan 1 no.lu kriterin referans noktasındaki koordinatı bu özniteliklerin alabileceği maksimum değer olan "1" değerlerinin toplamı olan " $\mathrm{n} 1$ = 3" değeri olacaktır. Herhangi bir istasyonun bu değere olan uzaklığ o istasyonun performans değeri olacağından bu uzaklıkların küçükten büyüğe doğru sıralanması ile de en iyiden en kötüye doğru istasyonların sıralaması elde edilecektir.

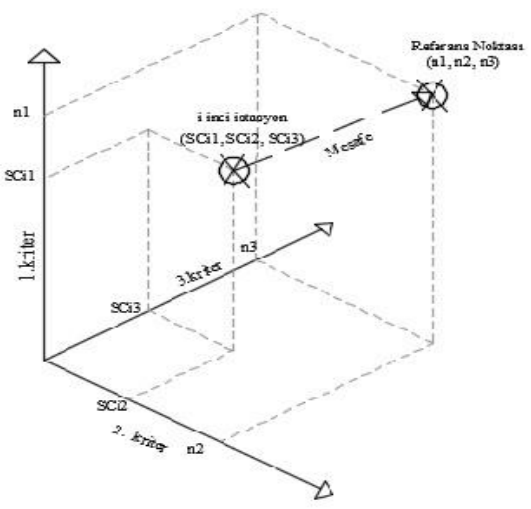

Şekil 1. Bir gözlem istasyonunun üç boyutlu karar alanındaki performansı

\section{Uygulama}

\subsection{Gediz havzası ve su kalitesi gözlem ağı}

Gediz Havzası Türkiye'nin batısında Ege Bölgesi'nde yer alır. Kuzey Ege, Susurluk ve Küçük Menderes Havzaları komşudur (Şekil 2). 1.703.394 ha alanı kaplayan havza, yükseklikleri 2000 m'yi bulan dağlar ile çevrelenmiş olup Ege Denizi'ne kadar uzanır. Havzanın adını aldığı Gediz Nehri 275 km uzunlukta olup, Murat Dağları'ndan doğar, Deli İniş, Demrek, Kum, Alaşehir ve Nif dereleri ile birleșerek Salihli ve Menemen Ovaları boyunca devam eder. Menemen Ovası'nı da geçerek Foça yakınlarında Ege Denizi'ne dökülür [24]. Havzada içmesuyu temini, sulama, taşkın koruma ve enerji üretimi amaçlı kullanılan 4 adet baraj ve birçok gölet bulunmaktadır. Havza genelinde sulama, kentsel, endüstriyel, çevresel koruma amaçlı su kullanımları ve Demirköprü barajında hidroelektrik enerji üretimi de mevcuttur.

Havzada Manisa, Kemalpașa, Ușak ve Menemen gibi birçok sanayi bölgesi ve Manisa, Akhisar, Turgutlu, Salihli gibi önemli yerleșimler bulunmaktadır. $\mathrm{Bu}$ bölgelerin ve yerleşimlerin atıksuları arıtılarak ya da doğrudan Gediz 
Nehri'ne deșarj edilmektedir. Diğer yandan orta ve așağı bölgelerde bulunan tarımsal alanlardan da yayılı kirlilik Gediz Nehri'ne karıșmaktadır [25]. Bu nedenlerle Gediz Nehri, hem su kalitesi hem de miktarı açısından tehdit altındadır ve özellikle su kalitesi gözlem ağından elde edilecek bilgilere göre yönetim hedeflerinin belirlenmesi büyük önem taşımaktadır.

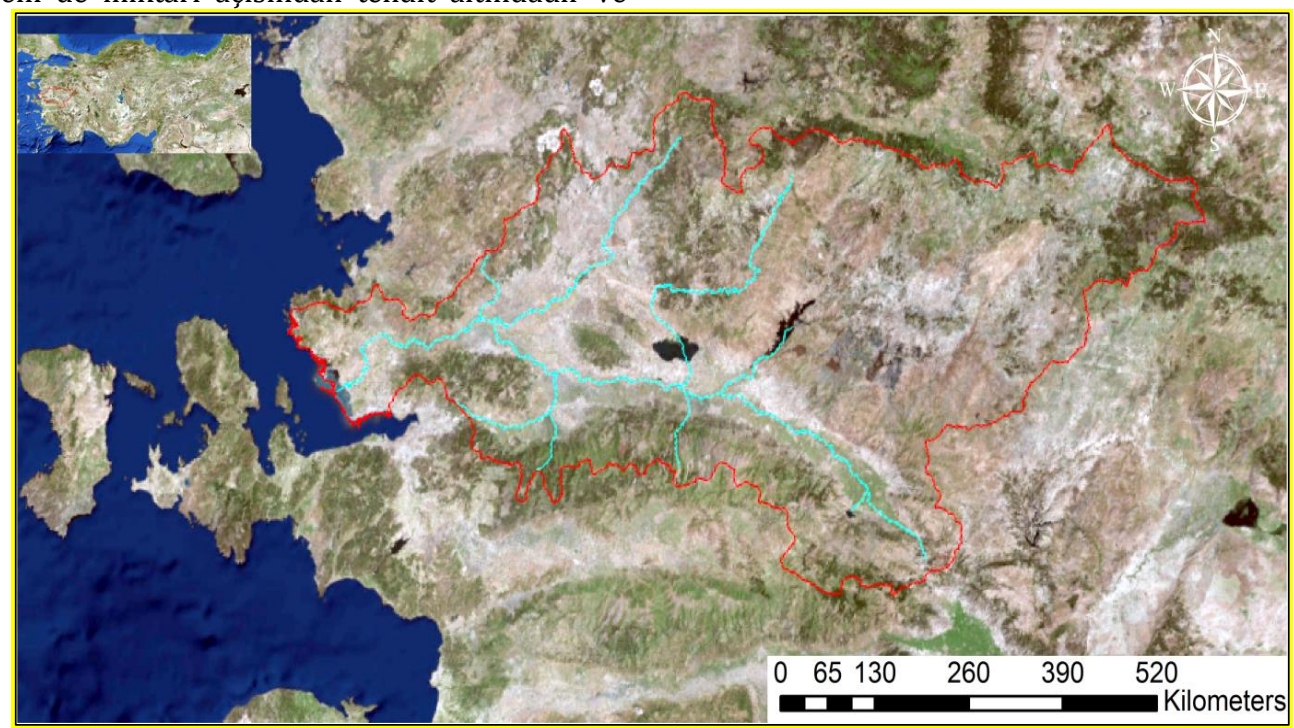

Şekil 2. Gediz Havzası sınırları

\subsection{Su kalitesi gözlem ağı}

Yapılan çalıșmada daha önce DSİ tarafından işletilen 1985-2000 yılları arasına ait 33 adet su kalite gözlem istasyonu verileri kullanılmıştır. Şekil 3'te çalışma kapsamında incelenen 19852000 yılları arası Gediz Havzası su kalitesi gözlem istasyonları gösterilmektedir. Su Kalitesi Kontrolü Yönetmeliği ve Yüzeysel Su Kalitesi Yönetimi Yönetmeliği'nde verilen genel şartlar ve ana parametre gruplarına göre sıcaklık, . sodyum, kalsiyum, klor, elektriksel iletkenlik, bulanıklık, $\mathrm{NH}_{3}-\mathrm{N}, \mathrm{NO}_{2}-\mathrm{N}, \mathrm{NO}_{3}-\mathrm{N}$, askıda katı madde, çözünmüş oksijen, BOD5 (biyolojik oksijen ihtiyacı), COD (kimyasal oksijen ihtiyacı) olmak üzere 13 adet parametre ile su kalitesi sınıfları tespit edilip, temsil ettikleri kirlilik gruplarına göre 2 gruba ayrılmıștır. Su kalitesi değişkenleri grupları Tablo 1'de gösterilmiştir.

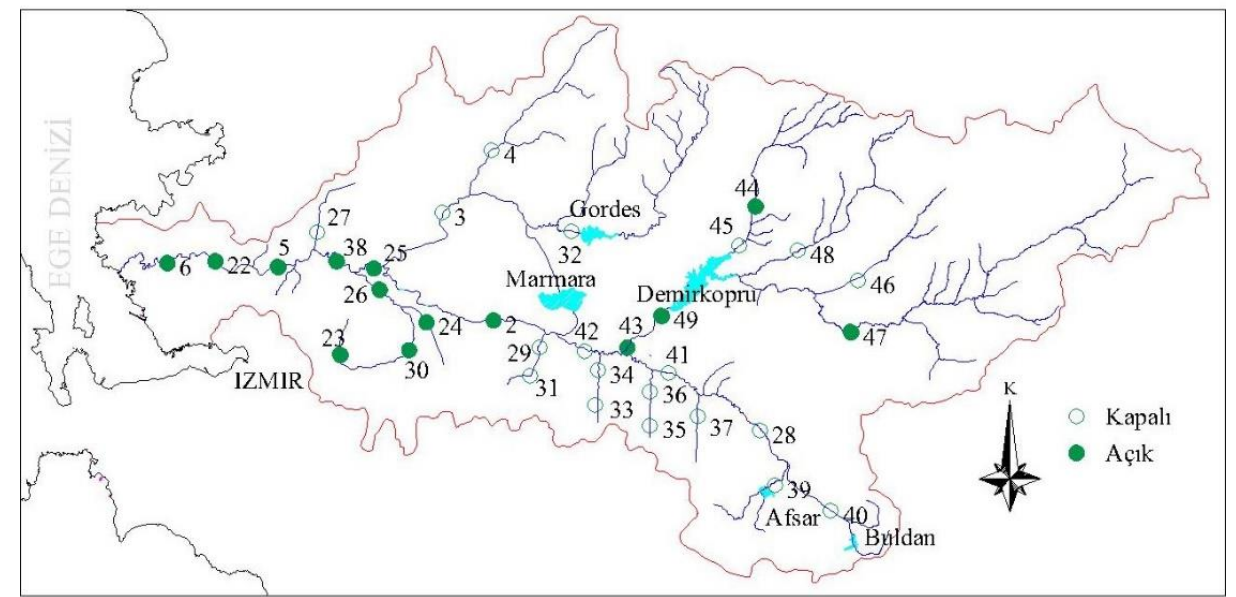

Şekil 3. Çalışma kapsamında incelenen 1985-2000 yılları arası Gediz Havzası su kalitesi gözlem istasyonları 
DEU FMD 21(62), 483-497, 2019

Tablo 1. Su kalitesi değişkenleri grupları.

\begin{tabular}{lll}
\hline Grup Adı & QSUM $_{1}$ & $\mathrm{QSUM}_{2}$ \\
\hline Temsil Edilen Kirlilik Yükü & $\begin{array}{l}\text { Sulama ve inorganik } \\
\text { maddelerden } \\
\text { yayılı kirlilik }\end{array}$ & $\begin{array}{l}\text { Organik madde, fosfat- } \\
\text { azot, evsel ve sulama } \\
\text { kaynaklı kirlilik }\end{array}$ \\
Değişkenler & $\mathrm{T}, \mathrm{Na}, \mathrm{Ca}, \mathrm{Cl}, \mathrm{EC}, \mathrm{Turb}$ & $\begin{array}{l}\mathrm{NH}_{3}-\mathrm{N}, \mathrm{NO}_{2}-\mathrm{N}, \mathrm{NO}_{3}-\mathrm{N}, \mathrm{SS} \\
\mathrm{BOD}, \mathrm{DO}\end{array}$ \\
\hline
\end{tabular}

\subsubsection{Amaç ve özniteliklerin belirlenmesi}

Gediz Havzası su kalitesi gözlem ağı için, su kalitesinin modellenmesi, mevcut durumun tespiti ve uzun süreli değişimlerin tespiti olmak üzere 3 amaç (kriter) belirlenmiștir. Su kalitesi modelleri; akarsu boyunca kalite değişimlerinin tespiti, elde edilen matematiksel modeller ile ortaya çıkabilecek ani deșarj v.b. durumlarda etkilenecek akarsu kesimlerinin tayini ve buna bağlı olarak alınabilecek önlemlerin kestirilmesi için kullanılan karar verme araçlarından biridir. $\mathrm{Bu}$ nedenle gözlem ağının hizmet edeceği amaçlardan biri olarak tayin edilmiștir. İkinci amaç olan mevcut durumun tespiti amacl, gözlem ağından elde edilen veriler ile su kalitesinin akarsu boyunca durumunu belirlemek ve sorunlu akarsu kesimlerinin tespitini sağlamayı kapsar. Uzun süreli değişimlerin tespiti amacı ise su kalitesinde var olan eğilimlerin belirlenmesi, bir yandan alınacak önlemleri tespit etmek diğer yandan da önceden alınmıș önlemlerin etkisini ölçmek işleri için gereklidir. Her bir amacl (kriteri) gerçekleştirmek için gerekli istasyon öznitelikleri (drenaj alanı, ișletme süresi, değişken gruplarının ortalama değerleri, gözlem sayısı, istasyon devamlılığı vb.) belirlenerek gruplandırılmıştır. Önceki bölümlerde de belirtildiği üzere, tanımlanan özniteliklerin tüm istasyonlar için geçerli olmasına, ölçülebilmesine ya da hesaplanabilir olmasına dikkat edilmiștir. Özniteliklerin tümü maksimizasyon esasına göre tayin edilmiștir, diğer bir deyişle öznitelikleri diğerlerinden büyük olan istasyonlar amaçlara daha iyi hizmet eden istasyonlar olarak değerlendirilmiștir. Bu özniteliklerin normalizasyon ve üniformizasyon işlemleri sonucunda $(0,1)$ aralı̆̆ında boyutsuz değerleri bulunarak, her kriter için toplam değerleri alınmış ve referans noktası değerlerine göre mesafeleri bulunarak bir sıralama elde edilmiştir.

Göz önüne alınan öznitelikleri daha detaylıca açıklamak gerekirse; Drenaj alanı (DrA) akarsudaki akıșın kalite değișkenlerinin tașıyıcı ortamı olduğu için, dikkate alınanan önemli özniteliklerden birisidir. Evsel kirliliğin belirlenmesi açısından nüfus (Pop), tarımsal ve sulama kaynaklı noktasal olmayan kirliliklerin belirlenmesi açısından sulama alanı (IrA) da öznitelik olarak seçilmiştir. İstasyonun getireceği bilginin ölçüsü olarak sayılabildiği için gözlem adedi (Snum) (ölçüm adedi fazla ise bilgi içeriğinin yüksek olması beklenir), uzun süreli gözlemlere sahip istasyonların korunması tercih edildiği için de işletme süresi (Oper) özniteliklere dahil edilmiştir. Ölçüm istasyonunda gözlenmiș su kalitesi değişkenlerinin ortalama değerlerini ifade eden kalite değișkenleri (Qsum\#), istasyonun veri toplamadaki sürekliliği (Cont.), örneğin yapılacak bir su derleme yapısı gibi spesifik bir amaca hizmet etme durumu (Pro), istasyonun ulaşılabilirliği (ulaşım) ve su kalitesi gözlem istasyonunun olduğu bölgede akım gözlem istasyonunun varlığı (AGI) gibi öznitelikler de göz önüne alınmıştır. Su kalitesi değişkenlerinin ortalama değerlerini ifade eden kalite değişkenlerinin (Qsum\#) belirlenmesi için kullanılabilecek standart bir yöntem bulunmadığından sulama ve inorganik maddelerden kaynaklı yayılı kirlilik ile evsel ve sulama kaynaklı kirlilik olmak üzere 2 grupta değerlendirilmiştir.

Su kalitesi gözlem ağı istasyonları performans değerlendirmesi için hedeflenen üç amaçta; su kalitesi modelleme için drenaj alanı, işletme süresi ve veri adedi amacı gerçekleştirmede önem arz eden öznitelikler olarak alınmıștır. Mevcut durum tespiti için nüfus yoğunluğu, sulama alanı, işletme süresi, veri adedi ve her bir grubu temsil eden kalite değișkenleri seçilmiștir. Uzun süreli değişim tespiti için ise nüfus yoğunluğu, sulama alanı, işletme süresi, veri adedi, ölçüm sıklığı, istasyonun ulaşılabilirliği,

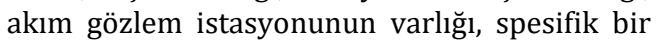
amaca hizmet edip etmediği gibi öznitelikler 
DEU FMD 21(62), 483-497, 2019

hesaba katılmıștır. Özellikle bu amaç su kalitesindeki iyiye ya da kötüye olan eğilimlerin belirlenmesinde önemlidir ve seçilen öznitelikler o istasyonun bu amaca hizmet etmekteki başarısını ölçmekte kullanılmıştır. Diğer yandan kirlilik gruplarındaki kalite değişkenlerinin ortalamaları ve değerleri birbirinden çok farklıdır, bu nedenle her bir istasyon için temel bileşenler analizi yapılmıș ve parametre gruplarında (Qsum) gözlenen parametrelerin kirlilik türüne yaptıkları katkı yüzde cinsinden hesaplanmıştır. Bu yüzdeler ile Qsum değerlerinin her istasyon için ortak ağırlıklı ortalamaları hesaplanarak üniformize edilmiștir. Tablo 2, Tablo 3 ve Tablo 4'te sırası ile su kalitesi modelleme, mevcut durum tespiti ve uzun süreli değişim tespiti amacına göre istasyon öznitelik değerleri verilmiştir.

Tablo 2. Su kalitesi modelleme amacına göre istasyon özellikleri.

\begin{tabular}{llll}
\hline $\begin{array}{l}\text { İstasyon } \\
\text { No }\end{array}$ & $\begin{array}{l}\text { Drenaj } \\
\text { Alanı (DrA) } \\
\left(\mathrm{km}^{2}\right)\end{array}$ & $\begin{array}{l}\text { Gözlem } \\
\text { Sayısı } \\
\text { (Snum) } \\
\text { (adet) }\end{array}$ & $\begin{array}{l}\text { İşletme } \\
\text { Süresi } \\
\text { (Oper) (yıl) }\end{array}$ \\
\hline 2 & $1.951,75$ & 990,00 & 16 \\
3 & $1.221,80$ & 361,00 & 8 \\
4 & 512,00 & 253,00 & 8 \\
5 & 179,30 & $1.057,00$ & 16 \\
6 & 168,40 & 750,00 & 16
\end{tabular}

\begin{tabular}{|c|c|c|}
\hline 186,50 & 753,00 & 11 \\
\hline 18,70 & 436,00 & 11 \\
\hline 414,30 & 662,00 & 10 \\
\hline 406,80 & 202,00 & 2 \\
\hline 549,60 & 772,00 & 11 \\
\hline 52,30 & 148,00 & 2 \\
\hline 694,30 & 110,00 & 2 \\
\hline 3,40 & 127,00 & 2 \\
\hline 343,40 & 759,00 & 10 \\
\hline 104,85 & 244,00 & 2 \\
\hline $1.444,00$ & 118,00 & 2 \\
\hline 100,36 & 239,00 & 2 \\
\hline 16,80 & 236,00 & 2 \\
\hline 12,16 & 239,00 & 2 \\
\hline 50,33 & 174,00 & 2 \\
\hline 36,81 & 88,00 & 2 \\
\hline $1.118,80$ & 669,00 & 10 \\
\hline 545,00 & 249,00 & 2 \\
\hline 180,00 & 230,00 & 2 \\
\hline $1.148,19$ & 515,00 & 10 \\
\hline 603,84 & 239,00 & 2 \\
\hline 216,00 & 624,00 & 10 \\
\hline 735,32 & 518,00 & 10 \\
\hline 23,35 & 183,00 & 2 \\
\hline 654,40 & 203,00 & 2 \\
\hline $2.945,00$ & 612,00 & 10 \\
\hline 637,40 & 170,00 & 2 \\
\hline $1.594,53$ & 641,00 & 10 \\
\hline
\end{tabular}


DEU FMD 21(62), 483-497, 2019

Tablo 3. Mevcut durum tespiti amacına göre istasyon özellikleri.

\begin{tabular}{|c|c|c|c|c|c|c|}
\hline İstasyon No & Nüfus (Pop) & $\begin{array}{l}\text { Sulama Alanı } \\
\text { (IrA) (ha) }\end{array}$ & $\begin{array}{l}\text { İşletme } \\
\text { Süresi } \\
\text { (Oper) } \\
\text { (yll) }\end{array}$ & $\begin{array}{l}\text { Gözlem } \\
\text { Sayısı Snum } \\
\text { (adet) }\end{array}$ & $\mathrm{QSUM}_{1}$ & $\mathrm{QSUM}_{2}$ \\
\hline 2 & 68.314 & $26.830,00$ & 16 & 990,00 & 948,09 & 161,40 \\
\hline 3 & 120.017 & $3.483,75$ & 8 & 361,00 & 772,91 & 310,29 \\
\hline 4 & 23.963 & $6.755,24$ & 8 & 253,00 & 593,78 & 186,70 \\
\hline 5 & 113.567 & $1.252,70$ & 16 & $1.057,00$ & $1.097,15$ & 170,80 \\
\hline 6 & 162.069 & $6.997,00$ & 16 & 750,00 & $1.014,81$ & 170,54 \\
\hline 22 & 3.079 & $2.088,87$ & 11 & 753,00 & $1.088,61$ & 42,17 \\
\hline 23 & 5.100 & $1.893,42$ & 11 & 436,00 & 695,95 & 35,89 \\
\hline 24 & 18.207 & $42.157,10$ & 10 & 662,00 & $1.113,11$ & 47,69 \\
\hline 25 & 45.457 & $13.053,25$ & 2 & 202,00 & 939,87 & 24,10 \\
\hline 26 & 18.887 & $13.712,50$ & 11 & 772,00 & $1.116,35$ & 100,01 \\
\hline 27 & 5.978 & $2.491,99$ & 2 & 148,00 & 604,39 & 17,91 \\
\hline 28 & 20.762 & $16.010,00$ & 2 & 110,00 & $1.447,58$ & 31,18 \\
\hline 29 & 5.407 & $4.766,40$ & 2 & 127,00 & 431,87 & 21,57 \\
\hline 30 & 30.506 & $4.629,00$ & 10 & 759,00 & $2.279,81$ & 72,42 \\
\hline 31 & 886 & 855,10 & 2 & 244,00 & 489,86 & 15,93 \\
\hline 32 & 25.642 & $9.638,12$ & 2 & 118,00 & 498,03 & 18,17 \\
\hline 33 & 803 & 464,19 & 2 & 239,00 & 677,24 & 16,55 \\
\hline 34 & 886 & 488,62 & 2 & 236,00 & 679,72 & 18,22 \\
\hline 35 & 886 & 158,80 & 2 & 239,00 & 523,08 & 16,17 \\
\hline 36 & 221 & 280,96 & 2 & 174,00 & 431,58 & 17,06 \\
\hline 37 & 886 & $1.062,76$ & 2 & 88,00 & 320,02 & 15,47 \\
\hline 38 & 57.018 & $2.430,91$ & 10 & 669,00 & 965,07 & 44,79 \\
\hline 39 & 20.600 & $4.275,46$ & 2 & 249,00 & 858,31 & 13,24 \\
\hline 40 & 13.504 & $2.846,24$ & 2 & 230,00 & 715,30 & 13,91 \\
\hline 41 & 64.439 & $16.760,00$ & 10 & 515,00 & 877,43 & 45,67 \\
\hline 42 & 87.905 & $2.683,00$ & 2 & 239,00 & 862,34 & 27,86 \\
\hline 43 & 7.172 & $2.207,11$ & 10 & 624,00 & 984,72 & 28,63 \\
\hline 44 & 31.716 & $7.023,98$ & 10 & 518,00 & 823,94 & 35,57 \\
\hline 45 & 6.499 & 976,89 & 2 & 183,00 & $1.240,99$ & 26,56 \\
\hline 46 & 19.333 & $6.962,90$ & 2 & 203,00 & 838,74 & 18,56 \\
\hline 47 & 38.227 & $2.218,00$ & 10 & 612,00 & 985,50 & 52,82 \\
\hline 48 & 14.695 & $6.352,12$ & 2 & 170,00 & 728,03 & 14,57 \\
\hline 49 & 40.034 & $17.114,65$ & 10 & 641,00 & 802,19 & 20,72 \\
\hline
\end{tabular}


DEU FMD 21(62), 483-497, 2019

Tablo 4. Uzun süreli değişim tespiti amacına göre istasyon özellikleri.

\begin{tabular}{|c|c|c|c|c|c|c|c|c|}
\hline İstasyon No & Nüfus (Pop) & $\begin{array}{l}\text { Sulama } \\
\text { Alanı } \\
\text { (IrA) (ha) }\end{array}$ & $\begin{array}{l}\text { İşletme } \\
\text { Süresi } \\
\text { (Oper) } \\
\text { (yil) }\end{array}$ & $\begin{array}{l}\text { Gözlem } \\
\text { Sayısı } \\
\text { Snum } \\
\text { (adet) }\end{array}$ & $\begin{array}{l}\text { Süreklilik } \\
\text { (Cont) }\end{array}$ & $\begin{array}{l}\text { Amaç } \\
\text { (Pro) }\end{array}$ & Ulaşım & AGI \\
\hline 2 & 68.314 & $26.830,00$ & 16 & 990,00 & 0,22 & 1 & 0,33 & 1 \\
\hline 3 & 120.017 & $3.483,75$ & 8 & 361,00 & 0,16 & 0 & 0,00 & 0 \\
\hline 4 & 23.963 & $6.755,24$ & 8 & 253,00 & 0,11 & 0 & 0,00 & 0 \\
\hline 5 & 113.567 & $1.252,70$ & 16 & $1.057,00$ & 0,24 & 1 & 0,66 & 1 \\
\hline 6 & 162.069 & $6.997,00$ & 16 & 750,00 & 0,17 & 1 & 1,00 & 0 \\
\hline 22 & 3.079 & $2.088,87$ & 11 & 753,00 & 0,25 & 1 & 0,66 & 0 \\
\hline 23 & 5.100 & $1.893,42$ & 11 & 436,00 & 0,14 & 1 & 1,00 & 1 \\
\hline 24 & 18.207 & $42.157,10$ & 10 & 662,00 & 0,24 & 1 & 0,33 & 1 \\
\hline 25 & 45.457 & $13.053,25$ & 2 & 202,00 & 0,37 & 0 & 0,00 & 0 \\
\hline 26 & 18.887 & $13.712,50$ & 11 & 772,00 & 0,25 & 1 & 0,66 & 1 \\
\hline 27 & 5.978 & $2.491,99$ & 2 & 148,00 & 0,27 & 0 & 0,00 & 0 \\
\hline 28 & 20.762 & $16.010,00$ & 2 & 110,00 & 0,20 & 0 & 0,00 & 0 \\
\hline 29 & 5.407 & $4.766,40$ & 2 & 127,00 & 0,23 & 0 & 0,00 & 0 \\
\hline 30 & 30.506 & $4.629,00$ & 10 & 759,00 & 0,28 & 1 & 1,00 & 0 \\
\hline 31 & 886 & 855,10 & 2 & 244,00 & 0,44 & 0 & 0,00 & 0 \\
\hline 32 & 25.642 & $9.638,12$ & 2 & 118,00 & 0,21 & 0 & 0,00 & 0 \\
\hline 33 & 803 & 464,19 & 2 & 239,00 & 0,43 & 0 & 0,00 & 0 \\
\hline 34 & 886 & 488,62 & 2 & 236,00 & 0,43 & 0 & 0,00 & 0 \\
\hline 35 & 886 & 158,80 & 2 & 239,00 & 0,43 & 0 & 0,00 & 0 \\
\hline 36 & 221 & 280,96 & 2 & 174,00 & 0,32 & 0 & 0,00 & 0 \\
\hline 37 & 886 & $1.062,76$ & 2 & 88,00 & 0,16 & 0 & 0,66 & 1 \\
\hline 38 & 57.018 & $2.430,91$ & 10 & 669,00 & 0,24 & 1 & 1,00 & 0 \\
\hline 39 & 20.600 & $4.275,46$ & 2 & 249,00 & 0,45 & 0 & 0,00 & 0 \\
\hline 40 & 13.504 & $2.846,24$ & 2 & 230,00 & 0,42 & 0 & 0,00 & 0 \\
\hline 41 & 64.439 & $16.760,00$ & 10 & 515,00 & 0,19 & 1 & 0,66 & 1 \\
\hline 42 & 87.905 & $2.683,00$ & 2 & 239,00 & 0,43 & 0 & 0,00 & 0 \\
\hline 43 & 7.172 & $2.207,11$ & 10 & 624,00 & 0,23 & 0 & 0,33 & 1 \\
\hline 44 & 31.716 & $7.023,98$ & 10 & 518,00 & 0,19 & 1 & 1,00 & 0 \\
\hline 45 & 6.499 & 976,89 & 2 & 183,00 & 0,33 & 0 & 0,00 & 0 \\
\hline 46 & 19.333 & $6.962,90$ & 2 & 203,00 & 0,37 & 0 & 0,00 & 0 \\
\hline 47 & 38.227 & $2.218,00$ & 10 & 612,00 & 0,22 & 1 & 1,00 & 0 \\
\hline 48 & 14.695 & $6.352,12$ & 2 & 170,00 & 0,31 & 0 & 0,00 & 0 \\
\hline 49 & 40.034 & $17.114,65$ & 10 & 641,00 & 0,23 & 1 & 0,67 & 0 \\
\hline
\end{tabular}

Temel Bileşenler Analizi birden çok değişkenin birbirinden bağımsız olmamaları durumunda, aralarındaki bağımlılığın yok edilmesi veya boyut indirgeme amacıyla kullanılmaktadır $[26,27,28]$. Çalışmada, Qsum gruplarını oluşturan parametre birimleri ve gözlem uzunluklarının birbirinden farklı olması nedeniyle, her grubu en iyi temsil eden değișken ve kovaryansın tespiti için Temel Bileşenler Analizi kullanılmış ve analizin varyanskovaryans matrisinden yararlanılmıștır. Değişkenler, ortak gözlem yılları matrisi olușturularak grupları temsil etme derecelerine göre sıralanmıștır. Grupları oluşturan parametrelerin ortak gözlemlendiği dönemlere göre gruba $\% 10$ ve üzeri oranda sağladıkları katkıya göre parametrelerin grubu temsil ettiği kabul edilmiștir. Farklı parametrelerin Qsum grubuna koyduğu katkı yani kirlilik temsil yüzdeleri kullanılarak her istasyon için Qsum değerleri hesaplanmıș ve bu değerler normalize ve üniformize edilerek Qsum skorları belirlenmiștir.

Yöntemde kullanılan toplam modelinin birim uyușmazlığı sorunuyla bașa çıkmak için, tanımlanan öznitelikler de benzer șekilde 0 ile 1 aralığ arasında normalize ve üniformize edilmiştir. Bununla birlikte, süreklilik, ulaşılabilirlik, akım gözlem istasyonunun varlığı 
ve istasyonun spesifik bir amaca hizmet edip etmemesi var ve yok yani " 0 " ve "1" değerlerini aldıkları için oldukları gibi kullanılmıştır. Her istasyonun tayin edilen amaçlara göre skoru (SC $\mathrm{C}_{\mathrm{im}}$ ) Eşitlik 6'da verilen toplam modeli kullanılarak hesaplanmıştır. Bu hesaplamada her amaç için tanımlanan öznitelik değerleri toplanmıştır. Elde edilen bu skor o amaç için o istasyonun karar uzayındaki koordinatlarından biri haline gelmektedir. Gözlem kriterleri göz önüne alındığında, mükemmel bir istasyonun tüm öznitelik skorları "1" olacağından o amac için referans noktası koordinatı dikkate alınan özniteliklerin sayısı haline gelmektedir. Buna göre, "su kalitesi modelleme" kriteri için mükemmel bir istasyon "3", "mevcut durum tespiti" kriteri için "6" ve "uzun süreli değişim tespiti" kriteri için "8" skoruna sahip olmalıdır. İki amaca göre değerlendirmede "su kalitesi modelleme"ve "mevcut durum tespiti" çift amacı için referans karar uzayı iki boyutlu bir düzlem haline gelmekte ve referans noktası koordinatı $(3,6)$ olmaktadır. Benzer şekilde "su kalitesi modelleme" ve "uzun süreli değișim tespiti" ikili amacinda referans noktası $(3,8)$, "mevcut durum tespiti" ve "uzun süreli değișim tespiti" amaç çiftinde $(6,8)$ değerlerini almaktadır. Her üç amaç birden değerlendirildiğinde karar uzayı Şekil 1'de olduğu gibi üç boyutlu bir hal alacak ve referans noktası $(3,6,8)$ koordinatlarında bulunacaktır. Bu noktalara daha yakın koordinatlarda bulunan istasyonlar, belirtilen gözlem kriterleri açısından o amaçların herbirine daha iyi hizmet eden istasyonlardır. Diğer bir deyişle Eşitlik 7'de verilen Öklid mesafesi referans noktasına en kisa olan istasyon gözetilen amaçları en iyi yerine getiren istasyondur. Şekil 4'te Amaç 1 ve Amaç 2'nin değerlendirildiği karar uzayı örnek olarak verilmiștir. Bu yolla her bir kritere göre ayrı ayrı, ikili ve üçlü amaçların birden değerlendirildiği durumlarda istasyonların referans noktasına yakınlıklarına göre bir sıralama elde edilmiștir. Tablo 6'da tek amaç, Tablo 7'de amaç çiftleri ve Tablo 8'de her üç amaç birden gözetildiğinde elde edilen istasyon performans siralamaları verilmektedir.

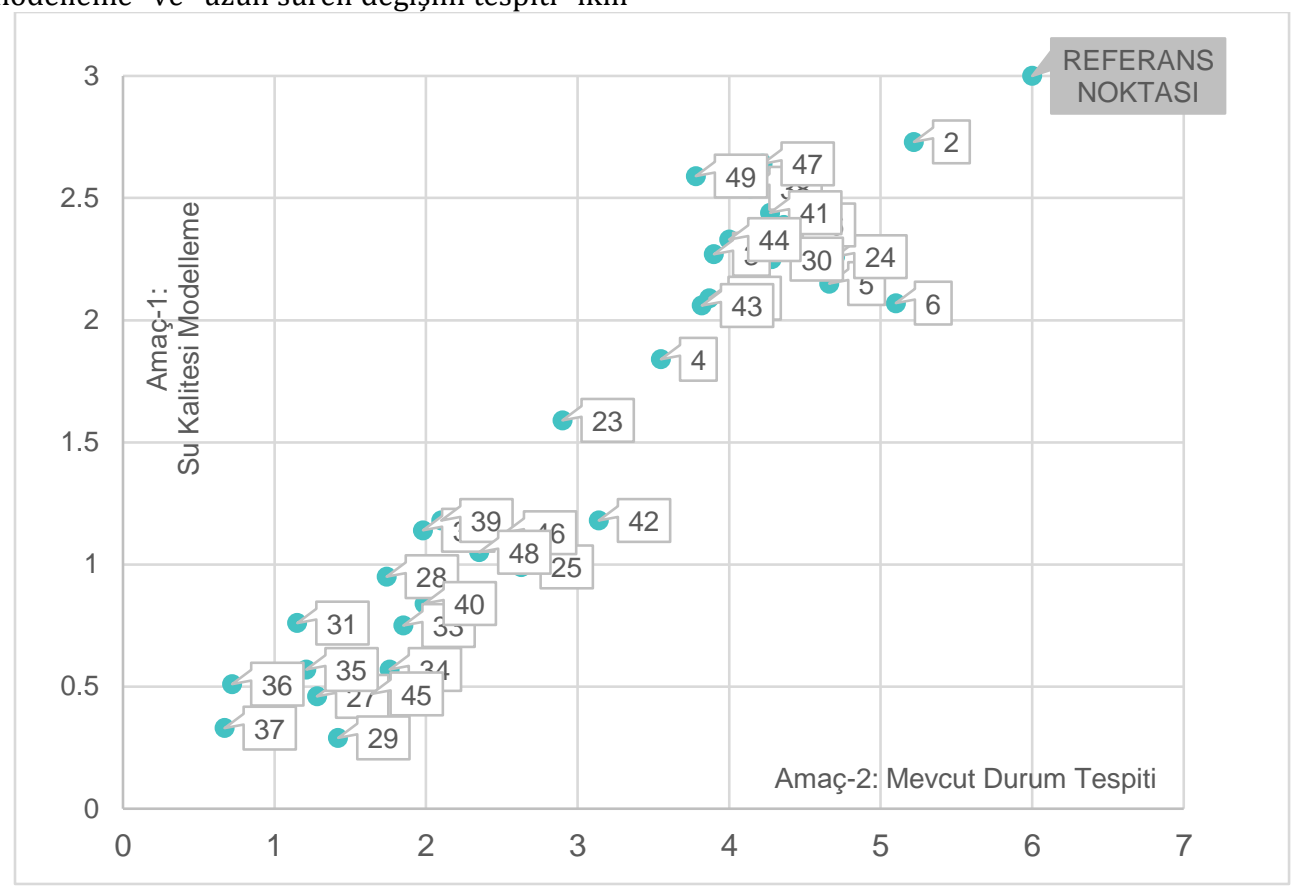

Şekil 4. Amaç 1 ve Amaç 2'nin birlikte değerlendirildiği alternatif istasyonların skorları ve referans noktası 
DEU FMD 21(62), 483-497, 2019

Tablo 6. Tek amaçlı referans noktası yaklașımının sonuçları.

\begin{tabular}{|c|c|c|c|c|c|c|}
\hline \multirow{2}{*}{ Sira No } & \multicolumn{2}{|c|}{ (Amaç-1) } & \multicolumn{2}{|c|}{ (Amaç-2) } & \multicolumn{2}{|c|}{ (Amaç-3) } \\
\hline & Ístasyon & Uzaklık & İstasyon & Uzaklık & İstasyon & Uzaklık \\
\hline 1 & 2 & 0,27 & 2 & 0,78 & 41 & 1,82 \\
\hline 2 & 47 & 0,36 & 6 & 0,90 & 2 & 1,84 \\
\hline 3 & 49 & 0,41 & 24 & 1,30 & 26 & 1,97 \\
\hline 4 & 38 & 0,46 & 5 & 1,34 & 5 & 2,15 \\
\hline 5 & 41 & 0,56 & 26 & 1,64 & 24 & 2,25 \\
\hline 6 & 26 & 0,61 & 30 & 1,72 & 6 & 2,44 \\
\hline 7 & 44 & 0,67 & 41 & 1,73 & 30 & 2,77 \\
\hline 8 & 3 & 0,73 & 47 & 1,78 & 49 & 2,79 \\
\hline 9 & 24 & 0,74 & 38 & 1,86 & 23 & 2,80 \\
\hline 10 & 30 & 0,75 & 44 & 2,00 & 44 & 2,86 \\
\hline 11 & 5 & 0,85 & 3 & 2,10 & 38 & 2,87 \\
\hline 12 & 22 & 0,91 & 22 & 2,13 & 47 & 3,05 \\
\hline 13 & 6 & 0,93 & 43 & 2,18 & 22 & 3,86 \\
\hline 14 & 43 & 0,94 & 49 & 2,22 & 43 & 4,13 \\
\hline 15 & 4 & 1,16 & 4 & 2,45 & 3 & 4,68 \\
\hline 16 & 23 & 1,41 & 42 & 2,86 & 4 & 5,08 \\
\hline 17 & 42 & 1,82 & 23 & 3,10 & 25 & 5,27 \\
\hline 18 & 39 & 1,82 & 25 & 3,37 & 42 & 5,43 \\
\hline 19 & 32 & 1,86 & 46 & 3,48 & 39 & 5,61 \\
\hline 20 & 46 & 1,87 & 48 & 3,65 & 46 & 5,66 \\
\hline 21 & 48 & 1,95 & 39 & 3,90 & 37 & 5,72 \\
\hline 22 & 25 & 2,01 & 40 & 4,01 & 28 & 5,80 \\
\hline 23 & 28 & 2,05 & 32 & 4,02 & 32 & 5,82 \\
\hline 24 & 40 & 2,16 & 33 & 4,15 & 48 & 5,89 \\
\hline 25 & 31 & 2,24 & 34 & 4,24 & 40 & 5,92 \\
\hline 26 & 33 & 2,25 & 28 & 4,26 & 29 & 6,35 \\
\hline 27 & 34 & 2,43 & 45 & 4,36 & 27 & 6,45 \\
\hline 28 & 35 & 2,43 & 29 & 4,58 & 31 & 6,49 \\
\hline 29 & 36 & 2,49 & 27 & 4,72 & 45 & 6,51 \\
\hline 30 & 45 & 2,53 & 35 & 4,79 & 33 & 6,59 \\
\hline 31 & 27 & 2,54 & 31 & 4,85 & 34 & 6,59 \\
\hline 32 & 37 & 2,67 & 36 & 5,28 & 35 & 6,64 \\
\hline 33 & 29 & 2,71 & 37 & 5,33 & 36 & 6,92 \\
\hline
\end{tabular}


DEU FMD 21(62), 483-497, 2019

Tablo 7. İki amaçlı referans noktası yaklaşımının sonuçları.

\begin{tabular}{|c|c|c|c|c|c|c|}
\hline \multirow{2}{*}{ Sira No } & \multicolumn{2}{|c|}{ (Amaç-1-2) } & \multicolumn{2}{|c|}{ (Amaç-2-3) } & \multicolumn{2}{|c|}{ (Amaç-1-3) } \\
\hline & Ístasyon & Uzaklık & Ístasyon & Uzaklık & Ístasyon & Uzaklık \\
\hline 1 & 2 & 0,8216 & 2 & 1,9993 & 2 & 1,8616 \\
\hline 2 & 6 & 1,2927 & 41 & 2,5121 & 41 & 1,9081 \\
\hline 3 & 24 & 1,4928 & 5 & 2,5291 & 26 & 2,0622 \\
\hline 4 & 5 & 1,5833 & 26 & 2,5614 & 5 & 2,3073 \\
\hline 5 & 26 & 1,7480 & 24 & 2,5932 & 24 & 2,3652 \\
\hline 6 & 47 & 1,8167 & 6 & 2,5962 & 6 & 2,6084 \\
\hline 7 & 41 & 1,8169 & 30 & 3,2652 & 49 & 2,8219 \\
\hline 8 & 30 & 1,8800 & 38 & 3,4260 & 30 & 2,8741 \\
\hline 9 & 38 & 1,9213 & 44 & 3,4942 & 38 & 2,9116 \\
\hline 10 & 44 & 2,1134 & 47 & 3,5340 & 44 & 2,9405 \\
\hline 11 & 3 & 2,2201 & 49 & 3,5691 & 47 & 3,0741 \\
\hline 12 & 49 & 2,2610 & 23 & 4,1798 & 23 & 3,1384 \\
\hline 13 & 22 & 2,3126 & 22 & 4,4077 & 22 & 3,9666 \\
\hline 14 & 43 & 2,3772 & 43 & 4,6757 & 43 & 4,2386 \\
\hline 15 & 4 & 2,7133 & 3 & 5,1265 & 3 & 4,7361 \\
\hline 16 & 42 & 3,3915 & 4 & 5,6423 & 4 & 5,2129 \\
\hline 17 & 23 & 3,4064 & 42 & 6,1372 & 25 & 5,6404 \\
\hline 18 & 25 & 3,9265 & 25 & 6,2558 & 42 & 5,7231 \\
\hline 19 & 46 & 3,9476 & 46 & 6,6417 & 39 & 5,8958 \\
\hline 20 & 48 & 4,1413 & 39 & 6,8303 & 46 & 5,9610 \\
\hline 21 & 39 & 4,3064 & 48 & 6,9323 & 32 & 6,1131 \\
\hline 22 & 32 & 4,4327 & 32 & 7,0795 & 28 & 6,1519 \\
\hline 23 & 40 & 4,5578 & 40 & 7,1487 & 48 & 6,2074 \\
\hline 24 & 33 & 4,7252 & 28 & 7,1991 & 40 & 6,2989 \\
\hline 25 & 28 & 4,7276 & 33 & 7,7870 & 37 & 6,3132 \\
\hline 26 & 34 & 4,8894 & 37 & 7,8155 & 31 & 6,8654 \\
\hline 27 & 45 & 5,0380 & 29 & 7,8345 & 29 & 6,9073 \\
\hline 28 & 29 & 5,3219 & 45 & 7,8360 & 27 & 6,9357 \\
\hline 29 & 31 & 5,3361 & 34 & 7,8383 & 33 & 6,9618 \\
\hline 30 & 27 & 5,3618 & 27 & 7,9975 & 45 & 6,9857 \\
\hline 31 & 35 & 5,3751 & 31 & 8,1000 & 34 & 7,0226 \\
\hline 32 & 36 & 5,8334 & 35 & 8,1868 & 35 & 7,0700 \\
\hline 33 & 37 & 5,9591 & 36 & 8,7030 & 36 & 7,3543 \\
\hline
\end{tabular}

Tablo 8. Üç amaçlı referans noktası yaklaşımının sonuçları.

\begin{tabular}{lll}
\hline \multirow{2}{*}{ Sıra No } & \multicolumn{2}{c}{ Amaç 1-2-3 } \\
\cline { 2 - 3 } & İstasyon & Uzaklık \\
\hline 1 & 2 & 2,0172 \\
2 & 41 & 2,5742 \\
3 & 26 & 2,6333 \\
4 & 5 & 2,6671 \\
5 & 24 & 2,6970 \\
6 & 6 & 2,7582 \\
7 & 30 & 3,3509 \\
8 & 38 & 3,4573 \\
9 & 47 & 3,5525 \\
10 & 44 & 3,5582 \\
11 & 49 & 3,5926 \\
12 & 23 & 4,4116 \\
13 & 22 & 4,5005 \\
14 & 43 & 4,7686 \\
15 & 3 & 5,1788 \\
16 & 4 & 5,7607 \\
17 & 42 & 6,4001 \\
18 & 25 & 6,5714
\end{tabular}

\begin{tabular}{lll}
\hline \multirow{2}{*}{ Sıra No } & \multicolumn{2}{c}{ Amaç 1-2-3 } \\
\cline { 2 - 3 } & İstasyon & Uzaklık \\
\hline 19 & 46 & 6,9003 \\
20 & 39 & 7,0696 \\
21 & 48 & 7,2021 \\
22 & 32 & 7,3191 \\
23 & 40 & 7,4684 \\
24 & 28 & 7,4841 \\
25 & 33 & 8,1065 \\
26 & 34 & 8,2056 \\
27 & 45 & 8,2336 \\
28 & 37 & 8,2598 \\
29 & 29 & 8,2890 \\
30 & 27 & 8,3909 \\
31 & 31 & 8,4029 \\
32 & 35 & 8,5411 \\
33 & 36 & 9,0515 \\
\hline
\end{tabular}




\section{Bulgular}

Gediz Havzası üzerinde, 1985-2000 yıllarına ait 33 adet su kalitesi gözlem istasyonunun farkl gözlem amaçları için değerlendirilmesi sonucunda özellikle 2, 5, 6, 24, 26, 30, 41 ve 44 numaralı istasyonların ön plana çıktığ görülmektedir. 38,47 ve 49 numaralı istasyonlarda birçok durumda sıralamanın üst kesiminde bulunmaktadırlar. Daha önce yapılmış olan ve 33 adet istasyonun 14 adede indirgenmesini hedefleyen TÜBİTAK YDABAG100Y102 numaralı projede [21] olduğu gibi bir ağ daraltma durumunda Referans Noktası Yöntemi'ne göre su kalitesi gözlem ağında öncelikli olarak tutulması gereken istayonlar yukarıda belirtilen istasyonlar olmalıdır. Değisşik amaçların seçilmesi durumunda ise farklı istasyonlar ön plana çıkabilmektedir. Örneğin, "uzun süreli değişim tespiti" amacına göre 23 no lu istasyon, "uzun süreli değişim tespiti" kriterini oluşturan AGİ ve Pro öznitelikleri açısından diğer istasyonlara göre daha iyi durumda olduğu için, yukarıda anılan istasyonlara ek olarak ilk 14 sıralamasına girebilmektedir. İki ve üç amaçlı durumlarda amaçların birisi "uzun süreli değişim tespiti" olduğu sürece 23 numaralı istasyon ilk 14 istasyon arasında kendine yer bulmaktadır.

\section{Tartışma ve Sonuç}

Devlet Su İşleri'nin Gediz Havzası'nda işlettiği 33 istasyonlu su kalitesi gözlem ağı 1998 yılında olduğu gibi daha az sayıya düşürülerek daraltılmak istendiğinde, ağın amaçları göz önüne alınarak korunacak istasyonlar Referans Noktası Yöntemi ile elde edilen sıralamadaki ilk 14 istasyon olarak belirlenebilmektedir. $\mathrm{Bu}$ sayede ağda tutulacak istasyonların hangileri olması gerektiğine yöntem ile karar verilebilir. Diğer yandan Referans Noktası Yöntemi farklı amaçların tek tek ya da bir arada gözetilmesi durumunda bu amaçlara en iyi hizmet eden istasyonların tespitinde de kullanılabilmektedir. Tersi bir çıkarım olarak da kötü durumda olan istasyonlar da ortaya çlkmakta ve bu istasyonların iyileștirilmesi gereken yönleri de irdelenebilmektedir. Örneğin, AGİ bulunmayan bir istasyon belirli amaca hizmet açısından düşük performans gösterirken, AGİ açılması kararı ile daha iyi bir hale gelebilir. Bu haliyle yöntem ağın işletilmesi ve amaçların yerine getirilmesi durumlarını irdelemekte rahatlıkla kullanılabilmektedir.
Referans noktası yöntemi, karar vericinin farklı birimdeki değișkenleri ve bağlı oldukları kriterleri ortak bütünde değerlendirmesini ve basit bir şekilde karar almasını sağlamaktadır. Karar vericiye farklı performans değerlendirme modellerini kullanma esnekliği de sunmaktadır. Herhangi bir ağırlık katsayısı gerektirmediği için, diğer yöntemlerde ortaya çıkabilecek öznel değerlendirmelerin etkilerini en aza indirgemekte ve nesnel bir yaklaşım sağlamakta, karșılașılan amaç sayısı, kriter ve öznitelikler arası önem sıralaması ve ağırlıklandırılması sorununu ortadan kaldırarak karar verme sürecini daha objektif temellere oturtmaya yardımcı olmaktadır $[14,29]$. $\mathrm{Bu}$ durum hedeflerin, kriterlerin ve özniteliklerin doğru olarak tanımlanması koşuluyla yöntemin değișebilecek her amaca göre adaptasyonunu kolaylaştırmaktadır. Ayrıca, bir özniteliğin birden fazla amaca katkıda bulunabiliyor olması özelliği, sınırlı ve düzensiz veriler içeren durumlarda karar vermeyi mümkün kılmaktadır. Belirtilen hedefler, karar alanının yalnızca bir boyutunu oluşturmaktadır, bu sebeple birçok paydaş birden fazla tercihi aynı anda sunabilir ve alternatifler arasındaki dengeler karar sonrası analiz sırasında daha şeffaf olarak belirlenebilir. Yöntemin uygulanmasında ortak amaç ve öznitelikler tarif edilebildiği sürece, sadece havza değil, meteorolojik, sismik, hava kalitesi v.b. gözlem ağların da olduğu gibi bölgesel hatta ülkesel ölçekte performans değerlendirmesi de yapılabilmektedir. Öte yandan, yöntem tek bir istasyonu kendi operasyonel amaçlarına göre de değerlendirebilir. Bu özellik de yöntemin bölge, ülke gibi büyük ölçeklerde kullanılabilmesini sağlamaktadır.

\section{Kaynakça}

[1] İçağa, Y. 1998. Spatial Optimization of Hydrometric Data Networks by System Analysis Techniques. Dokuz Eylül Üniversitesi, Fen Bilimleri Enstitüsü, Doktora Tezi, 164s, İzmir.

[2] Timmerman, J. G. 2014. Information Needs for Water Management. First edition. CRC Press Taylor \& Francis Group, 234s, ISBN-13: 978-1466594746, ISBN-10: 1466594748

[3] Özkul, S. 2001. Su Kalitesi Gözlem Ağlarının Entropi Yöntemi ile Değerlendirilmesi. Turk J Engin Environ Sci 25: 435-452.

[4] Sharp, W. E. 1971. A Topologically Optimum Water Sampling Plan for Rivers and Streams. Water Resources Research, 7 (6), 1641-1646. DOI: 10.1029/WR007i006p01641.

[5] Horton, R. E. 1945. Erosional Development of Streams. Geological Society Am. Bull., 56 (3), 275- 
DEU FMD 21(62), 483-497, 2019

370 , DOI:10.1130/0016-7606(1945)56[275 EDOSAT]2.0.CO;2.

[6] Tirsch, F. S. ve Male, J. W. 1984. River Basin Water Quality Monitoring Network Design: Options for Reaching Water Quality Goals. In T.M. Schad (Ed.) Proceedings of Twentieth Annual Conference of American Water Resources Associations, AWRA Publications, 149-156.

[7] Özkul, S. 1996. Space/Time Design of Water Quality Monitoring Networks by the Entropy Method (İngilizce). Dokuz Eylül Üniversitesi Fen Bilimleri Enstitüsü, Doktora Tezi, 196s, İzmir.

[8] Al-Zahrani, M. A., ve Moeid, K. 2001. Locating Optimum Water Quality Monitoring Stations in Water Distribution System. In Bridging the Gap: Meeting the World's Water and Environmental Resources Challenges, DOI: 10.1061/40569(2001)393.

[9] Çetinkaya, C. P. ve Harmancioğlu, N. B. 2011. Assessment of Water Quality Sampling Sites by a Dynamic Programming Approach. Journal of Hydrologic Engineering 17.2: 305-317, DOI: 10.1061/(ASCE)HE.1943-5584.0000420.

[10] Villas-Boas M.D., Olivera F., de Azevedo J.P.S 2017. Assessment of the Water Quality Monitoring Network of the Piabanha River Experimental Watersheds in Rio De Janeiro, Brazil, Using Autoassociative Neural Networks. Environmental Monitoring Assessment Cilt 189: 439 DOI 10.1007/s10661-017-6134-9

[11] Asadollahfardi G., Heidarzadeh N., Mosalli A., Sekhavati A. 2018. Optimization of Water Quality Monitoring Stations Using Genetic Algorithm, A Case Study, Sefid-Rud River, Iran. Advances in Environmental Research, Cilt. 7, No. 2 87-107. DOI: https://doi.org/10.12989/aer.2018.7.2.087

[12] Mokin V.B., Kryzhanovskyi Y.M., Yascholt A.R., Sobko B.Y., Slobodianiuk O.V. et al. 2018. The Method of Multi-Criteria Ranking of Monitoring Stations for Waterdischarge in Rivers for Determining Priorities of their Location. Proc. SPIE 10808, Photonics Applications in Astronomy, Communications, Industry, and High-Energy Physics Experiments 2018, 108082Q; doi:10.1117/12.2501640

[13] Harmancioğlu, N. B., Özkul, S. D. Ve Alpaslan, M. N. 1998. Water Quality Monitoring and Network Design. Environmental data management. Springer Netherlands, 61-106, DOI:10.1007/978-94-0159056-3_4.

[14] Vujic B., Srdjevic Z., Srdjevic B. 2017. Reference Point Approach for Multi-objective Assessment and Reduction of Ground-Level 03 Air Quality Monitoring Network in Vojvodina Province, Serbia Environ Model Assess (2017) 22:491-501. DOI 10.1007/s10666-017-9560-8

[15] Kallio, M., Lewandowski, A., \& Orchard-Hays, W 1980. An Implementation of the Reference Point Approach for Multiobjective Optimization. WP-8035. IIASA, Laxenburg, Austria, 29s.

[16] Wierzbicki, A. P. 1980. The Use of Reference Objectives in Multiobjective Optimization. In Fandel G. and Gal T. editors, MCDM Theory and Applications, Springer, Berlin, s 468-486, DOI: 10.1007/978-3642-48782-8_32.

[17] Wierzbicki, A. P. 1998. Reference Point Methods in Vector Optimization and Decision Support. IR-98-
017, International Institute for Applied Systems Analysis, Laxenburg, Austria, 43s.

[18] Wierzbicki, A. P. 2007. Reference Point Approaches and Objective Ranking. In Jürgen Branke, Kalyanmoy Deb, Kaisa Miettinen and Roman Slowinski, editors, Practical Approaches to Multi-Objective Optimization, number 06501 in Dagstuhl Seminar Proceedings, Dagstuhl, Germany. Internationales Begegnungs- und Forschungszentrum für Informatik, Schloss Dagstuhl, Germany, 20s, ISSN: 1862-4405.

[19] Ogryczak, W. 2010. Ordered Weighted Enhancement of Preference Modeling in the Reference Point Method for Multiple Criteria Optimization. Soft Computing 14.5 : 435-450, DOI: $10.1007 /$ s00500009-0457-6.

[20] Wierzbicki, A. P., Makowski, M., ve Wessels, J. 2000. Model Based Decision Support Methodology with Environmental Applications. Kluwer Academic Publishers, Dordrecht, The Netherlands, 475s, ISBN: 978-0-7923-6327-9.

[21] Harmancioğlu, N. B., Özkul, S., Fıstıkoğlu, O., Onuşluel G., Gül, A., Çetinkaya, C.P., İçağa, Y., Barbaros, F., Akyar, H., Kahramanoğlu, N., Seyrek, K., Baltacı, F., Onur, A. K., Yılmaz, N., Celtemen, S. P. ve Alpaslan, A. 2003. Efficiency Analysis and Network Optimization in DSI's Water Quality Monitoring Networks II (in Turkish). Report repared for the Research Project granted by TUBITAK, Scientific and Technical Research Council of Turkey, Project code: YDABAG 100Y1002, İzmir.

[22] Cetinkaya, C. P. 2007. Spatial Optimization of Hydrologic Monitoring Networks on Rivers. Dokuz Eylül Üniversitesi, Fen Bilimleri Enstitüsü, Doktora Tezi, 128s, İzmir.

[23] Gibbons, J. D. ve Chakraborti, S. 1992. Nonparametric Statistical Inference. 3rd edition. Marcel Dekker, Inc. New York, 572s, ISBN-10: 0824786610, ISBN-13: 978-0824786618.

[24] Çetin, H.C. ve diğer. 2009. Gediz Nehri Su Kalitesi Parametrelerinin Eğilim Analizi. TMMOB İzmir Kent Sempozyumu, İzmir, 603-611.

[25] TÜBİTAK MAM 2013. Gediz Havzası Nihai Raporu. http://gediz.ormansu.gov.tr/gediz/Files/Gediz\%20 Havzas\%C4\%B1\%20Nihai\%20Raporu.pdf (Erişim Tarihi: 02.11.2018).

[26] Arnold, S.F. 1981. The Theory of Linear Models and Multivariate Analysis. John Wiley and Sons, Inc., USA, 475s, ISBN 0-471-05065-2.

[27] Ludwig, J.A. ve Reynolds, J. F. 1988. Statistical Ecology. A Wiley-Intescience Publication., USA, 337s, ISBN 0-471-83235-9.

[28] Sharma, S. 1996. Applied Multivariate Techniques. John Wiley and Sons, Inc., USA, 493s, ISBN 0.471.31064.6

[29] Lictevout E., Gocht M. 2018. Hydrometric Network Design in Hyper-Arid Areas: Example of Atacama Desert (North Chile). Hydrology Research 49 (4): 1208-1220. https://doi.org/10.2166/nh.2017.004 